\title{
Pengaruh Tekanan Ketaatan dan Audit Internal Terhadap Perilaku Kecurangan Pelaporan Keuangan
}

\author{
Lu'lu' Nafiati \\ Fakultas Ekonomi dan Bisnis, Universitas Ahmad Dahlan \\ lulu.nafiati@act.uad.ac.id
}

\begin{abstract}
This study examines the effect of obedience pressure and internal audit function on fraudulent financial reporting behavior. Realities and previous studies have shown the strong effect of obedience pressure on fraudulent financial reporting behavior. However, few studies that examine mitigation strategies on that effect. This study proposes internal audit function to mitigate the effect of obedience pressure on fraudulent financial reporting behavior.

This study uses experimental design $2 x 2$ between subjects with students as surrogate. Hypothesis were tested by using ANOVA test. The results of study show that obedience pressure affects fraudulent financial reporting behavior. Moreover, auditor internal is not able to mitigate the effect of obedience pressure on fraudulent financial reporting behavior.
\end{abstract}

Keywords: Obedience Pressure, Internal Audit, Fraudulent Financial Reporting

\section{Latar Belakang}

Beberapa skandal akuntansi seperti yang terjadi pada WorldCom dan HealthSouth menunjukkan keterlibatan figur berotoritas yang memerintahkan bawahannya untuk terlibat dalam kecurangan pelaporan keuangan (Clam 2005). Realita tersebut didukung oleh penelitian Feng et al. (2011) yang memberikan bukti empiris bahwa CFO cenderung terlibat dalam kecurangan pelaporan keuangan akibat adanya tekanan dari CEO. CEO memiliki otoritas terkait karir serta kompensasi CFO, sehingga mampu menekan CFO terkait keputusan pelaporan keuangan. CFO dapat kehilangan pekerjaan serta keuntungan finansial lain jika tidak menaati perintah CEO (Feng et al. 2011). Hal ini sejalan dengan penelitian Milgram (1974) mengenai tekanan ketaatan yang menunjukkan bahwa $65 \%$ partisipan mengikuti perintah dari atasannya walaupun hal tersebut bertentangan dengan etika, nilai, dan kepercayaan mereka.

Pada konteks pelaporan keuangan, audit internal merupakan pengendali internal yang utama (Hooper dan Fornelli 2010). Melalui fungsi pengawasan, audit internal (yang selanjutnya disebut dengan AI) membantu perusahaan mencapai tujuannya untuk menghasilkan laporan keuangan yang dapat diandalkan dengan mengamati tindakan manajemen serta bertindak sebagai pencegah pelaporan keuangan yang agresif (Prawitt et al. 2009).

Literatur mengenai fungsi akuntansi menunjukkan bahwa AI memiliki peranan besar dalam menguatkan reliabilitas proses pelaporan keuangan dan pencegahan kecurangan (Arel et al. 2012). Pengujian eksperimen yang dilakukan Schneider dan Wilner (1990) menunjukkan bahwa keberadaan audit internal maupun eksternal memiliki peran pencegah dalam tindakan penyimpangan pelaporan keuangan. Penelitian-penelitian tersebut telah menunjukkan bahwa AI mampu mengurangi perilaku kecurangan pelaporan keuangan. Dengan demikian, diharapkan AI mampu mengurangi pengaruh tekanan ketaatan terhadap perilaku kecurangan pelaporan keuangan. Oleh karena itu, penting bagi peneliti untuk menguji secara empiris hubungan ketiga variabel tersebut. 
Penelitian ini memiliki dua isu utama yaitu mengenai pengaruh tekanan ketaatan terhadap perilaku kecurangan pelaporan keuangan dan strategi mitigasi yang dapat dilakukan untuk mengurangi pengaruh tekanan ketaatan terhadap perilaku kecurangan pelaporan keuangan. Untuk menjawab isu tersebut, penelitian menggunakan metode eksperimen laboratorium.

Pada penelitian ini, tekanan ketaatan mengacu pada tekanan untuk menuruti perintah dari pihak yang memiliki otoritas (DeZoort dan Lord 1994). Mengikuti penelitian yang dilakukan oleh Mayhew dan Murphy (2014), tekanan ketaatan dimanipulasi dengan bentuk keberadaan (ada vs. tidak ada). Sedangkan untuk AI, konsisten dengan penelitian sebelumnya yang dilakukan oleh Schneider dan Wilner (1990) terbagi menjadi dua kategori (ada vs. tidak ada).

\section{Kajian Literatur}

1. Kecurangan Pelaporan Keuangan

Kecurangan pelaporan keuangan merupakan salah saji yang disengaja atau penghapusan jumlah atau pengungkapan dalam laporan keuangan yang ditujukan untuk mengelabuhi pengguna laporan keuangan sehingga menyebabkan laporan keuangan, dalam semua hal yang material, tidak disajikan sesuai dengan prinsip akuntansi yang berlaku umum (AICPA, 2002). Kecurangan ini meliputi (a) manipulasi, pemalsuan, atau perubahan pencatatan akuntansi atau dokumen pendukung yang digunakan untuk menyusun laporan keuangan; (b) salah saji atau penghapusan yang disengaja mengenai kejadian signifikan atau transaksi dari laporan keuangan; (c) kesalahan penerapan yang disengaja atas aturan akuntansi (AICPA 2002).

Menurut literatur audit, kecurangan pelaporan keuangan disebabkan oleh adanya salah satu atau gabungan dari ketiga faktor berikut, yaitu: (i) adanya tekanan atau insentif untuk melakukan kecurangan; (ii) kodisi mendukung adanya kesempatan untuk terjadinya kecurangan; (iii) sikap atau rasionalisasi untuk melakukan kecurangan (AICPA 2002).

2. Teori ketaatan

Paradigma tekanan ketaatan pertama kali diperkenalkan oleh Stanley Milgram (1963). Penelitian Milgram (1963) menunjukkan bahwa 65\% partisipan mengikuti perintah dari atasannya walaupun hal tersebut bertentangan dengan etika, nilai, dan kepercayaan mereka. Penelitian-penelitian berikutnya yang menggunakan metode serupa dengan Milgram (1963) menunjukkan hasil yang serupa. Pada konteks akuntansi, tekanan ketaatan telah dibuktikan secara empiris mengenai pengaruhnya terhadap perilaku tidak etis. Davis et al. (2006) menggunakan tekanan ketaatan dalam kaitannya dengan kekenduran anggaran. Dari eksperimen yang dilakukannya, lebih dari separuh partisipan melanggar kebijakan tertulis dan melakukan kekenduran anggaran ketika dihadapkan dengan tekanan ketaatan dari atasannya. DeZoort dan Lord (1994) melakukan penelitian dengan menggunakan variabel tekanan ketaatan dalam konteks audit. Penelitian ini memberikan bukti empiris bahwa auditor junior akan menuruti perintah auditor yang lebih senior meskipun hal tersebut melanggar kode etik yang berlaku. Penelitian yang dilakukan oleh Mayhew dan Murphy (2014) juga menunjukkan bahwa bawahan akan melakukan kecurangan pelaporan keuangan ketika diperintahkan oleh atasannya.

3. Audit Internal

Audit internal merupakan aktivitas yang independen, objektif, dan konsultatif yang dirancang untuk menaikkan nilai dan memperbaiki operasi organisasi (IIA 2015). Audit internal (AI) bersama-sama dengan manajemen eksekutif, auditor eksternal, dan komite audit menjadi pilar good corporate governance yang membantu memastikan efektivitas pengendalian internal dan keaandalan pelaporan keuangan (IIA 2015). 
Salah satu peran AI adalah mengevaluasi dan mengawasi efektivitas dan efisiensi sistem pengendalian internal perusahaan (IIA 2015; Kaplan dan Schultz 2007). Melalui peran pengawasan, AI membantu perusahaan mencapai tujuannya dalam menghasilkan laporan keuangan yang handal dengan memeriksa tindakan manajemen dan bertindak sebagai pencegah pelaporan keuangan yang agresif (Prawitt et al. 2009). AI juga menyediakan jaminan atas efektivitas pengendalian internal (misalnya dengan memastikan bahwa semua transaksi telah didukung oleh dokumen yang memadai) melalui evaluasi rutin dan pengujian pengendalian serta mengawasi aktivitas sehari-hari manajemen (Arel et al. 2012).

AI telah diakui dalam literatur audit sebagai komponen penting dari corporate governance yang memegang peranan monitoring. Schneider dan Wilner (1990) menemukan bahwa baik auditor eksternal maupun internal memiliki efek pencegahan terhadap perilaku kecurangan pelaporan.

Penelitian eksperimen justru telah mendukung hasil-hasil hubungan ini sejak lama. Penelitian eksperimen yang menguji hubungan AI dengan kualitas pelaporan keuangan telah dilakukan oleh Asare et al. (2008), Gramling et al. (2004). Schneider dan Wilner (1990) melakukan pengujian dan menemukan hasil bahwa keberadaan audit internal maupun eksternal memiliki peran pencegah dalam tindakan penyimpangan pelaporan keuangan jika keempat kondisi berikut ada: jumlahnya material, penyimpangan melibatkan penyajian lebih atas aset, pelanggaran PABU yang jelas, sedikit insentif untuk melakukan salah saji terhadap pendapatan. Penelitian Asare et al. (2008) juga menunjukkan hasil yang serupa, yaitu auditor internal berhubungan terhadap niatan manajemen untuk memanipulasi informasi keuangan.

4. Pengembangan Hipotesis

Perilaku kecurangan pelaporan keuangan merupakan salah satu bentuk tindakan tidak etis. Jones dan Kavanagh (1996) menyatakan bahwa individu melakukan perbuatan tidak etis dalam organisasi disebabkan oleh adanya faktor individual dan faktor situsional. Faktor situasional yang mendasari terjadinya perilaku tidak etis salah satunya disebabkan oleh adanya tekanan manajerial (Jones dan Kavanagh 1996).

Penelitian Feng et al. (2011) memberikan bukti empiris bahwa CFO cenderung terlibat dalam kecurangan pelaporan keuangan akibat adanya tekanan dari CEO. CEO memiliki pengaruh yang siginifikan terhadap pelaporan keuangan, namun tidak memiliki akses secara langsung terhadap pelaporan keuangan. Oleh karena itu, CEO biasanya membutuhkan bantuan dari CFO untuk menjalankan niatnya melakukan kecurangan pelaporan keuangan (Aier et al. 2005). CEO memiliki otoritas terkait karir serta kompensasi CFO, sehingga mampu menekan CFO terkait keputusan pelaporan keuangan. CFO dapat kehilangan pekerjaan serta keuntungan finansial lain jika tidak menaati perintah CEO (Feng et al. 2011).

Hal ini juga diperkuat dengan penelitian yang dilakukan oleh Mayhew dan Murphy (2014). Berdasar penelitian tersebut, individu merasionalisasi perilaku kecurangan pelaporan keuangan dengan menempatkan tanggung jawab penuh kepada pihak yang memiliki otoritas daripada menempatkan tanggung jawab individu atas tindakan tersebut.

Berdasar dari penelitian-penelitian terkait tekanan ketaatan di atas ditemukan hasil yang relatif konsisten yang menunjukkan bahwa individu akan tetap melakukan tindakan yang diperintahkan oleh individu lain yang memiliki otoritas yang lebih tinggi meskipun tindakan tersebut bertentangan dengan nilai dan kepercayaan mereka. Dengan demikian, peneliti menyusun hipotesis sebagai berikut: 
H1: Individu yang memperoleh tekanan ketaatan akan lebih cenderung melakukan kecurangan pelaporan keuangan daripada individu yang tidak memperoleh tekanan ketaatan.

Literatur mengenai kecurangan menyatakan bahwa perilaku kecurangan seharusnya diuji berdasar pada 3 kategori risiko yaitu (i) adanya kesempatan untuk dilakukannya kecurangan (ii) adanya insentif atau tekanan yang mampu dijadikan sebagai alasan untuk terlibat dalam kecurangan (iii) adanya sikap yang dimiliki individu untuk melakukan rasionalisasi atas kecurangan yang dilakukan (AICPA 2002). Pada konteks pelaporan keuangan, AI merupakan pengendali internal yang utama (Hooper dan Fornelli 2010). Penelitian sebelumnya (Arel et al. 2012; Schneider dan Wilner 1990) menunjukkan bahwa AI mampu mencegah terjadinya kecurangan.

Hooper dan Fornelli (2010) menyatakan bahwa meskipun terdapat tekanan yang sangat kuat untuk melakukan kecurangan, kecurangan tidak akan dapat terjadi jika tidak ada kesempatan untuk melakukannya. Dengan demikian, peneliti menduga, meskipun CFO mendapatkan tekanan dari CEO untuk melakukan kecurangan terhadap laporan keuangan, jika perusahaan telah memiliki AI maka CFO akan merasa takut untuk menaati permintaan CEO.

H2: Pada kondisi adanya tekanan ketaatan, kecurangan pelaporan keuangan lebih rendah pada organisasi yang memiliki AI daripada organisasi yang tidak memiliki AI

\section{Metoda Penelitian}

1. Pengumpulan Data

Pengumpulan data dilakukan dengan metode eksperimen. Desain eksperimen menggunakan instrumen Mayhew dan Murphy (2014) dengan modifikasi minor untuk memasukkan manipulasi kualitas AI. Instrumen Mayhew dan Murphy (2014) digunakan untuk menguji pengaruh tekanan ketaatan terhadap perilaku kecurangan pelaporan. Untuk menambah pengujian kualitas AI, peneliti menggunakan alat uji yang digunakan Arel et al. (2012) yang disesuaikan dengan konteks pembelajaran. Sebelum melakukan eksperimen, pilot test dilakukan untuk melihat validitas instrumen yang digunakan.

2. Partisipan

Partisipan merupakan mahasiswa program sarjana di sebuah perguruan tinggi di Yogyakarta. Mahasiswa yang menjadi partisipan diharuskan telah mengikuti mata kuliah Pengauditan sehingga diharapkan mampu lebih memahami manipulasi yang diberikan. Partisipan diberikan insentif keuangan untuk memaksimalkan keseriusan terhadap instrumen yang dikerjakan dan juga untuk memacu partisipan melakukan kecurangan pelaporan pada sesi kuis saat eksperimen berlangsung. Partisipan memiliki kemungkinan mendapatkan insentif lebih tinggi dari seharusnya dengan cara melaporkan insentif yang didapatkan dari sesi kuis lebih tinggi dari yang seharusnya didapatkan.

3. Definisi Operasional dan Pengukuran Variabel

Variabel dependen pada penelitian ini adalah perilaku kecurangan pelaporan. Variabel independen dari penelitian ini terdiri dari 2 variabel, yaitu tekanan ketaatan dan kualitas.

Variabel perilaku kecurangan pelaporan diilustrasikan menggunakan instrumen yang digunakan Mayhew dan Murphy (2014). Perilaku kecurangan diukur dengan melihat proporsi kecurangan relatif terhadap jumlah total yang mungkin didapatkan (Mayhew dan Murphy 2014) dengan menggunakan perhitungan berikut:

$$
\mathrm{NPP}=\frac{\text { nilai yang dilaporkan }- \text { nilai yang seharusnya diperoleh }}{37.500-\text { nilai yang seharusnya diperoleh }} \times 100
$$


Jangkauan dari variabel ini adalah 0 (jujur) hingga 100 (melakukan kecurangan hingga nilai kemungkinan maksimal). Pengukuran ini diberi nama Nilai Perbedaan Pelaporan (NPP).

Variabel tekanan ketaatan digambarkan dengan partisipan mendapatkan manipulasi berupa tekanan ketaatan dari dosen yang memberikan pengajaran terhadap mata kuliah yang dievaluasi. Dosen melakukan manipulasi kepada partisipan dengan meminta kepada mahasiswa untuk menaikkan nilai yang dilaporkan karena penilaian tersebut akan mempengaruhi penilaian terhadap kinerja dosen.

Variabel kualitas AI diukur dengan mengadaptasi instrumen pengukuran yang digunakan oleh penelitian sebelumnya [lihat Arel et al. 2012; Gramling et al. 2004]. Variabel ini dibagi menjadi 2 kelompok ada AI dan tidak ada AI.

4. Prosedur Eksperimen

Eksperimen menggunakan desain $2 \times 2$ between subject dengan perlakuan berupa tekanan ketaatan dan kualitas AI. Partisipan dibagi menjadi 4 kelompok yang berbeda dengan perlakuan seperti pada desain eksperimen berikut.

\section{Tabel 1}

Distribusi Kelompok dalam Eksperimen

\begin{tabular}{|c|c|c|c|}
\hline \multicolumn{2}{|c|}{} & \multicolumn{2}{|c|}{ AI } \\
\cline { 3 - 4 } \multicolumn{2}{|c|}{} & Ada & Tidak Ada \\
\hline \multirow{2}{*}{$\begin{array}{l}\text { Tekanan } \\
\text { ketaatan }\end{array}$} & Ada & Kel A & Kel B \\
\cline { 2 - 4 } & Tidak Ada & Kel C & Kel D \\
\hline
\end{tabular}

Pada sesi eksperimen, partisipan dihadapkan dengan dosen yang menggambarkan pihak yang memiliki otoritas dan pemeriksa yang menggambarkan anggota AI. Tahapan eksperimen dilakukan dengan urutan sebagai berikut:

1. Partisipan memasuki ruang kelas untuk mengikuti perkuliahan rutin yang diajarkan oleh dosen. Dosen memberikan materi perkuliahan seperti biasa. Eksperimen dilakukan di dua kelas secara bersamaan untuk membagi kelompok yang memperoleh perlakuan tekanan ketaatan dan tanpa perlakuan tekanan ketaatan.

2. Setelah penyampaian materi berakhir, dosen menjelaskan kepada partisipan bahwa akan ada penelitian yang bertujuan untuk menguji kualitas pengajaran dosen. Penelitian dilakukan oleh pihak dekanat. Desepsi ini akan dijelaskan pada saat debriefing. Partisipan boleh menolak untuk ikut serta dalam penelitian ini, sehingga penelitian ini bersifat sukarela.

3. Peneliti memasuki ruangan dan membagikan instrumen eksperimen yang terdiri dari (i) lembar soal (ii) lembar jawaban (iii) lembar pelaporan nilai (iv) amplop berisi lembar cek manipulasi.

4. Peneliti menjelaskan bahwa partisipan akan mendapat insentif uang sebesar Rp 2.500 bila jawaban benar, minus Rp 1.500 bila jawaban salah, minus Rp 1.700 bila tidak menjawab. Dosen akan menerima insentif uang sebesar sepuluh kali lipat dari rata-rata insentif partisipan.

5. Partisipan diminta mengerjakan soal kemudian mengisi jawaban di lembar jawaban. Soal berjumlah 15 soal dan harus diselesaikan dalam waktu 10 menit.

6. Partisipan diminta mengoreksi jawabannya sendiri dengan menyimak jawaban yang benar yang disebutkan oleh peneliti.

7. Partisipan diminta melaporkan nilai yang diperoleh di lembar nilai yang diberikan untuk kemudian dikumpulkan. Partisipan diberitahu bahwa hanya lembar nilai saja yang dikumpulkan. Hal ini akan memberikan celah bagi partisipan untuk melakukan kecurangan. 
8. Peneliti membagikan insentif kepada partisipan sesuai dengan jumlah yang tercantum pada lembar nilai.

9. Partisipan diminta membuka amplop dan menjawab pertanyaan cek manipulasi yang diberikan.

10. Partisipan diberi penjelasan bahwa evaluasi yang dilakukan merupakan eksperimen penelitian dan penjelasan mengenai desepsi yang dilakukan peneliti. Partisipan mengisi formulir ketersediaan sebagai partisipan.

Partisipan dikelompokkan secara acak ke dalam 4 kelompok yang tersedia. Pada kondisi adanya tekanan ketaatan, dosen memberikan manipulasi pada tahapan ekperimen nomor 6 . Instruksi ini tidak dilakukan secara tertulis melainkan berupa instruksi langsung yang diucapkan oleh dosen dengan menggunakan ekspresi yang natural. Dengan demikian, partisipan tidak akan merasa bahwa mereka sedang diikutsertakan dalam eksperimen.

5. Cek Manipulasi

Dua pertanyaan diberikan kepada partisipan setelah partisipan mengumpulkan lembar nilai. Pertama, "Apakah nilai dosen bergantung pada nilai yang Anda peroleh pada evaluasi ini?"(Rafinda 2013). Kedua, "Apakah akan ada pemeriksaan terhadap nilai yang dilaporkan?" (Kaplan dan Schultz 2007).

6. Analisis dan Pengujian Hipotesis

Hipotesis diuji dengan menggunakan uji kontras pada ANOVA. Hipotesis pertama berbunyi individu yang memperoleh tekanan ketaatan akan lebih cenderung melakukan kecurangan pelaporan keuangan daripada individu yang tidak memperoleh tekanan ketaatan. Hipotesis ini dijawab dengan membandingkan NPP dari sel A, B dengan C, D. Hipotesis akan terdukung jika NPP sel A, B memiliki nilai lebih tinggi dibandingkan sel C, D.

Hipotesis kedua berbunyi pada kondisi adanya tekanan ketaatan, kecurangan pelaporan keuangan lebih rendah pada organisasi yang memiliki AI daripada organisasi yang tidak memiliki AI. Hipotesis ini dijawab dengan membandingkan NPP dari sel A dengan sel B. Hipotesis akan terdukung jika NPP sel A memiliki nilai lebih rendah dibandingkan sel B.

\section{Hasil dan Pembahasan}

1. Data Demografi dan Cek Manipulasi

Kriteria subjek dalam penelitian ini adalah mahasiswa sarjana jurusan Akuntansi yang telah mengambil mata kuliah Pengauditan. Jumlah subjek yang bersedia menjadi partisipan penelitian adalah sebanyak 70 orang. Sebanyak 13 partisipan tidak berhasil menjawab pertanyaan cek manipulasi, sehingga jumlah partisipan yang dapat digunakan adalah sebanyak 57 orang. Partisipan dibagi ke dalam dua kelas untuk membedakan kelompok yang mendapat perlakuan tekanan ketaatan dan tidak mendapat perlakuan tekanan ketaatan.

Untuk menjamin kesetaraan antar kelompok eksperimen dilakukan dengan memastikan bahwa randomisasi partisipan dalam pembagian kelompok telah berjalan dengan baik. 
Tabel 2

Statistik Deskriptif Semua Kelompok

\begin{tabular}{|c|c|c|c|}
\hline \multicolumn{2}{|c|}{} & \multicolumn{2}{|c|}{ Kualitas AI } \\
\cline { 3 - 4 } \multicolumn{2}{|c|}{} & Ada & Tidak Ada \\
\hline \multirow{4}{*}{$\begin{array}{c}\text { Tekanan } \\
\text { Ketaatan }\end{array}$} & $\frac{\text { Kel A }}{\mathrm{N}: 15}$ & $\frac{\text { Kel B }}{\mathrm{N}: 15}$ \\
\cline { 3 - 4 } & & Mean: 10,87 & Mean: 16,13 \\
& & SD: 14,03 & SD: 14,48 \\
& \multirow{3}{*}{ Tidak Ada } & $\frac{\text { Kel C }}{\mathrm{N}: 14}$ & $\frac{\text { Kel D }}{\mathrm{N}: 13}$ \\
& & Mean: 0,00 & Mean: 1,00 \\
& & SD: 0,00 & SD: 3,61 \\
\hline
\end{tabular}

Berdasarkan tabel di atas, dapat diketahui bahwa jumlah partisipan yang mendapatkan perlakuan tekanan ketaatan adalah sebanyak 30 subjek dan jumlah partisipan yang tidak mendapatkan perlakuan tekanan ketaatan adalah sebanyak 27 subjek. Data ini digunakan untuk melakukan pengujian H1. Selanjutnya, kelompok partisipan yang mendapatkan perlakuan tekanan ketaatan akan dibandingkan kembali pada sub kelompok yang mendapatkan kondisi ada AI dan tidak ada AI. Data ini digunakan untuk melakukan pengujian $\mathrm{H} 2$.

2. Pengujian dan Pembahasan Hipotesis

a. Pengujian dan Pembahasan Hipotesis 1

Hipotesis 1 memprediksi bahwa individu yang memperoleh tekanan ketaatan akan lebih cenderung melakukan kecurangan pelaporan keuangan daripada individu yang tidak memperoleh tekanan ketaatan. Pengujian hipotesis 1 dilakukan dengan dua tahap, yaitu: (i) membandingkan nilai mean antar kelompok; (ii) menguji signifikansi perbedaan dengan analisis kontras ANOVA.

\section{Tabel 3}

Statistik Deskriptif Hipotesis 1

\begin{tabular}{lccc}
\hline Perlakuan & N & Mean & SD \\
\hline Terdapat Tekanan Ketaatan & 30 & 13,5 & 14,26 \\
Tanpa Tekanan Ketaatan & 27 & 0,48 & 2,50 \\
\hline
\end{tabular}

Tabel 4

Uji ANOVA

\begin{tabular}{ccc}
\hline Tes Statistik & Signifikansi \\
\hline ANOVA H1 & Kel A, B $\neq$ Kel C, D & 0,000 \\
\hline
\end{tabular}

Berdasarkan Tabel 4.2, hipotesis 1 memenuhi syarat pertama yaitu kelompok A, B memiliki rata-rata nilai perbedaan pelaporan (NPP) lebih tinggi dibanding kelompok D, E yaitu 13,5 dibanding 0,48. Lebih lanjut, pada tabel 4.3 ditemukan bahwa uji hipotesis 1 menunjukkan hasil yang signifikan karena memiliki nilai signifikansi kurang dari 0,005, yaitu sebesar 0,000. Dengan demikian, hipotesis 1 terdukung oleh data.

Temuan ini mengkonfirmasi temuan-temuan uji eksperimen sebelumnya (ew dan Murphy 2014; Rafinda 2013) yang menyatakan bahwa tekanan ketaatan berpengaruh terhadap perilaku kecurangan pelaporan keuangan. Temuan ini juga mengkonfirmasi penelitian Feng et al. (2011) yang menggunakan 2.261 data dari Accounting and Auditing Enforcement Releases yang dikeluarkan oleh SEC dari tahun 1982 hingga 2005 mengenai salah saji pelaporan keuangan yang melanggar US GAAP. Penelitian Feng et al. (2011) menemukan bukti empiris bahwa CEO merupakan pihak yang paling banyak mengajak kecurangan pelaporan $(31,9 \%)$ serta pihak yang paling banyak mendapat manfaat (42,5\%), sedangkan CFO bukanlah pihak yang paling banyak mengajak $(17,5 \%)$ serta bukan pihak yang paling banyak memperoleh manfaat $(7,5 \%)$. Dengan demikian, Feng et al. (2011) berkesimpulan bahwa keterlibatan CFO dalam perilaku kecurangan 
pelaporan keuangan sebagian besar merupakan akibat dari perintah CEO ketimbang dari inginnya memperoleh keuntungan pribadi. Hal ini disebabkan karena CEO memiliki peran penting terhadap CFO terutama terkait dengan dampak negatif potensial pada karir dan pekerjaan (DeZoort dan Lord 1994).

Penelitian ini juga menguatkan teori ketaatan Milgram $(1963,1974)$ yang menyatakan bahwa individu cenderung akan mengikuti perintah dari atasannya walaupun hal tersebut bertentangan dengan etika, nilai, dan kepercayaan mereka. Penelitian ini memberikan bukti bahwa teori ketaatan juga berlaku pada konteks perilaku kecurangan pelaporan keuangan. Penelitian sebelumnya terkait akuntansi juga menunjukkan bahwa tekanan ketaatan juga terjadi pada konteks kekenduran anggaran (Davis et al. 2006) dan pengauditan (DeZoort dan Lord 1994).

b. Pengujian dan Pembahasan Hipotesis 2

Hipotesis 2 memprediksi bahwa pada kondisi adanya tekanan ketaatan, individu yang berada pada kondisi ada AI akan lebih cenderung tidak melakukan kecurangan pelaporan keuangan daripada individu yang berada pada kondisi tidak ada AI. Pengujian hipotesis 2 dilakukan dengan dua tahap, yaitu: (i) membandingkan nilai mean antar kelompok; (ii) menguji signifikansi perbedaan dengan analisis kontras ANOVA. Hipotesis 2 diterima apabila mean NPP pada kelompok A ditemukan lebih rendah dibandingkan kelompok B. Berikut adalah tabel yang menggambarkan statistik deskriptif dan ANOVA uji kontras.

\section{Tabel 5}

Statistik Deskriptif Hipotesis 2

\begin{tabular}{lccc}
\hline \multicolumn{1}{c}{ Perlakuan } & N & Mean & SD \\
\hline Terdapat Tekanan, ada AI & 15 & 10,87 & 14,02 \\
Terdapat Tekanan, tidak ada AI & 15 & 16,13 & 14,48 \\
\hline
\end{tabular}

Tabel 6

Uji ANOVA H2

\begin{tabular}{ccc}
\hline Tes Statistik & Signifikansi \\
\hline ANOVA H2 & Kel A $\neq$ Kel B & 0,52 \\
\hline
\end{tabular}

Berdasarkan Tabel 4.4, hipotesis 2 memenuhi syarat pertama yaitu kelompok A memiliki rata-rata nilai perbedaan pelaporan (NPP) lebih rendah dibanding kelompok B, yaitu 10,87 dibanding 16,13. Lebih lanjut, pada tabel 4.5 ditemukan bahwa uji hipotesis 2 menunjukkan hasil yang signifikan karena memiliki nilai signifikansi lebih dari 0,005, yaitu 0,52. Dengan demikian, hipotesis 2 tidak terdukung oleh data.

Temuan ini menguatkan tidak sejalan dengan hasil temuan-temuan terdahulu (Arel et al. 2012; Asare et al. 2008; Gramling et al. 2004; Prawitt et al. 2009; Schneider dan Wilner 1990) yang menyatakan bahwa AI mampu mencegah terjadinya kecurangan. Adanya tekanan dari atasan menyebabkan AI tidak memiliki peran dalam mencegah terjadinya kecurangan pelaporan keuangan.

Penelitian ini membandingkan pengujian antara ada dan tidaknya AI. Menurut Prawitt et al. (2009) terdapat dua jenis kualitas AI, yaitu AI kuat dan AI lemah. Kedua kualitas ini memiliki dampak yang berbeda dalam upaya pencegahan manajemen laba. Berdasar penelitian tersebut, sebaiknya dilakukan penelitian lebih lanjut mengenai apakah terdapat pengaruh kualitas AI (kuat dan lemah) terhadap perilaku kecurangan pelaporan keuangan pada kondisi adanya tekanan ketaatan.

Prawitt et al. (2009) yang menguji kualitas AI dengan menggunakan data empiris mengkonsepkan kualitas AI ke dalam proksi: kepada siapakah AI memberikan laporannya (komite audit versus manajemen); tingkatan kefokusan AI terhadap kinerja keuangan yang 
diukur dengan menggunakan waktu yang dihabiskan untuk melakukan audit kinerja keuangan; ukuran AI

Pada penelitian berikutnya, kualitas AI dapat digambarkan dengan menunjukkan kondisi kuat dan lemah yang terbagi menjadi (i) kepada siapakah pemeriksa melaporkan hasil kerjanya (pemeriksa dekanat vs. dosen); (ii) peran utama pemeriksa (melakukan pemeriksaan vs. memberikan pendampingan); (iii) kinerja yang dihasilkan pemeriksa (selalu menemukan kecurangan vs. tidak pernah menemukan adanya kecurangan).

\section{Simpulan dan Saran}

Penelitian ini memberikan beberapa hasil pengujian. Pertama, hasil penelitian memberikan bukti empiris bahwa tekanan ketaatan berpengaruh terhadap perilaku kecurangan pelaporan keuangan. Individu yang memperoleh tekanan dari atasannya cenderung akan menuruti perintah atasannya meskipun hal ini bertentangan dengan nilai, etika, dan kepercayaannya. Hal ini disebabkan karena atasan memiliki peranan yang kuat terhadap keputusan masa depan karir individu tersebut (Feng et al. 2011). Selain itu, individu juga cenderung akan memindahkan tanggung jawabnya kepada pihak yang memerintahkan perbuatan tersebut (Mayhew dan Murphy 2014). Dengan demikian, ketika individu diperintahkan untuk melakukan kecurangan pelaporan keuangan, individu cenderung akan menuruti perintah tersebut.

Kedua, penelitian ini belum menunjukkan keterdukungan bukti atas kemampuan AI dalam memitigasi perilaku kecurangan pelaporan keuangan pada kondisi adanya tekanan ketaatan. Atas hasil ini, peneliti mengusulkan adanya penelitian lebih lanjut dengan membagi AI menjadi dua kategori yaitu AI kuat dan AI lemah.

Penelitian ini mempunyai beberapa keterbatasan sebagai berikut. Pertama, penelitian ini belum memasukkan faktor individual dalam mempengaruhi perilaku kecurangan pelaporan keuangan. Menurut literatur etika, perilaku tidak etis disebabkan oleh faktor disposisional (atau sering disebut sebagai faktor internal individu) dan faktor situasional (Jones 1991). Oleh karena itu, penting bagi peneliti selanjutnya untuk memasukkan faktor individual ke dalam model ini.

Kedua, penelitian ini baru menguji pengaruh tekanan ketaatan terhadap salah satu dari tiga jenis kecurangan yang ada. Penting bagi penelitian berikutnya, untuk menguji pengaruh tekanan terhadap kecurangan dalam bentuk penyalahgunaan aset dan korupsi yang lebih sering terjadi dibanding kecurangan pelaporan keuangan.

\section{Referensi}

AICPA. (2002). Consideration of Fraud in a Financial Statement Audit. SAS No. 99. New York: AICPA.

Aier, J. K., Comprix, J., Gunlock, M. T., \& Lee, D. (2005). The Financial Expertise of CFOs and Accounting Restatements. Accounting Horizons, 19(3), 123-135.

Arel, B., Beaudoin, C. A., \& Cianci, A. M. (2012). The Impact of Ethical Leadership, the Internal Audit Function, and Moral Intensity on a Financial Reporting Decision. Journal of Business Ethics, 109(3), 351-366.

Asare, S. K., Davidson, R. A., \& Gramling, A. A. (2008). Internal Auditors' Evaluation of Fraud Factors in Planning an Audit: The Importance of Audit Committee Quality and Management Incentives. International Journal of Auditing, 12(3), 181-203.

Davis, S., DeZoort, F. T., \& Kopp, L. S. (2006). The Effect of Obedience Pressure and Perceived Responsibility on Management Accountants' Creation of Budgetary Slack. Behavioral Research in Accounting, 18, 19-35. 
DeZoort, F. T., \& Lord, A. T. (1994). An Investigation of Obedience Pressure Effects on Auditors' Judgments. Behavioral Research in Accounting, 6, 1-29.

Feng, M., Ge, W., Luo, S., \& Shevlin, T. (2011). Why do CFOs Become Involved in Material Accounting Manipulations? Journal of Accounting and Economics, 51(1-2), 21-36.

Gramling, A. a, Maletta, M. J., Schneider, A., \& Church, B. K. (2004). The Role of the Internal Audit Function in Corporate Governance: a Synthesis of the Extant Internal Auditing Literature and Directions for Future Research. Journal of Accounting Literature, 23, 194244.

Hooper, M., \& Fornelli, C. (2010). Deterring and Detecting Financial Reporting Fraud: A Platform for Action. Washington: The Center for Audit Quality.

IIA. (2015). International Professional Practice Framework. Florida: The Institute of Internal Auditors.

Jones, G. E., \& Kavanagh, M. J. (1996). An Experimental Examination of the Effects of Individual and Situational Factors on Unethical Behavioral Intentions in the Workplace. Journal of Business Ethics, 15(5), 511-523.

Kaplan, S. E., \& Schultz, J. J. (2007). Intentions to Report Questionable Acts: An Examination of the Influence of Anonymous Reporting Channel, Internal Audit Quality, and Setting. Journal of Business Ethics, 71(2), 109-124.

Mayhew, B. W., \& Murphy, P. R. (2014). The Impact of Authority on Reporting Behavior, Rationalization and Affect. Contemporary Accounting Research, 31(2), 420-443.

McClam, E. (2005). WorldCom CFO Told "to Hit Numbers." Capital Journal Magazine. http://cjonline.com/stories/020905/bus_worldcom.shtml\#.VnbqyV40rT5

Milgram, S. (1974). Obedience to Authority. New York: Harper \& Row, 4(6), 613.

Prawitt, D. F., Smith, J. L., \& Wood, D. a. (2009). Internal audit quality and earnings management. Accounting Review, 84(4), 1255-1280.

Rafinda, A. (2013). Kemampuan Prediksi Faktor Situasional dan Faktor Individual pada Perilaku Kecurangan Pelaporan. Simposium Nasional Akuntansi XVI.

Schneider, A., \& Wilner, N. (1990). A Test of Audit Deterrent to Financial Reporting Irregularities Using the Randomized Response Technique. The Accounting Review, 65(3), 668-681. 